\title{
Effects of Electrical Stimulation on the \\ Peptide and Free Amino Acid Contents \\ of Beef Homogenate and Sarcoplasma \\ during Storage
}

\author{
Masayuki Mikami, Mari Nagao, Mitsuo Sekikawa, \\ Hiroyuki Mrura and Yasuhisa Hongo* \\ Laboratory of Meat Preservation, Obihiro University of \\ Agriculture and Veterinary Medicine, Obihiro-shi 080 \\ * Hokkaido Prefectural Shintoku Animal Husbandry Experimental \\ Station, Shintoku-machi, Hokkaido 081
}

(Received May 26, 1994)

\begin{abstract}
To investigate the peptide and free amino acid contents of beef treated with electrical stimulation (ES), Hereford steers were slaughtered. ES was carried out at a low voltage $(40 \mathrm{~V}$ and $13.8 \mathrm{~Hz}$ ) for 0 (cont.), $30 \mathrm{sec}$ (ES30) and $60 \mathrm{sec}$ (ES60). Homogenate and sarcoplasma from $M$. biceps femoris muscles were prepared and stored at $2 \pm 1^{\circ} \mathrm{C}$ for $0(6 \mathrm{hrs}), 2,7,14$ and 21 days after slaughter. The peptide contents in the both ES 30 and ES 60 homogenates were greater than in the control from day 0 after slaughter. The amount of peptides in the control, the ES30 and the ES60 homogenates were $162.5,192,1$ and $198.6 \mathrm{mg}$ per $100 \mathrm{~g}$ meat on day 0 , respectively and 356.4 , 409.7 and $405.5 \mathrm{mg}$ per $100 \mathrm{~g}$ meat 21 days after slaughter, respectively. The total amount of free amino acids increased during storage, but did not significantly differ between the control and the ES homogenates. However, the content of Glu increased with ES treatment from day 0 ; measuring $23.3,31.1$ and $32.0 \mathrm{mg}$ per $100 \mathrm{~g}$ meat in the control, the ES30 and the ES60 homogenates 21 days after slaughter, respectively. It is seemed that ES contributed to the improvement of meat flavor or taste, by increasing the peptides and free amino acids, especially Glu. In the stored sarcoplasma, the peptide and free amino acid contents were also investigated under the same conditions as the homogenate. Total amounts of peptides and free amino acids increased during storage in the sarcoplasma also, although these increment corresponded to $45.8-48.5 \%$ and $53.9-$ $69.7 \%$ of the homogenate storage 21 days after slaughter, respectively. These findings indicate that origins of peptides and free amino acids are derived from myofibrillar proteins as well as sarcoplasma.
\end{abstract}

Anim. Sci. Technol. (Jpn.) 65 (11) : 1034-1043, 1994

Key words : electrical stimulation, sarcoplasma, peptides, amino acids, meat conditioning

Many studies have been carried out on the effects of ES during post-mortem storage ; ES has been recognized as a means of improving tenderness of the muscle. This improvement is related to the avoidance of cold-shortening, increased muscle fibre fracture, accelerated ageing by lysosomal enzymes at low $\mathrm{pH}$ and to the effect of calpains in the very early post- mortem period in which the $\mathrm{pH}$ is relatively high $^{3,4,9,21)}$. ES was also found to enhance the rate of troponin- $T$ degradation during ageing of muscles ${ }^{1,10)}$. Muscle proteolytic enzymes, calpains and lysosomal proteases (cathepsins B and $L$ ), appear to be involved in the conditioning process of meat and these proteases may enhance each other's effects ${ }^{18)}$. Dutson et al. ${ }^{4}$ 


\section{Effects of Electrical Stimulation on Beef}

have also reported that lysosomal membranes are disrupted and that the activity of free lysosomal enzymes increases after ES. Therefore, increased tenderness of ES meat may be due to the increased rate of enzymes released from the lysosomes into the rapidly acidifying environment within the muscle fiber and the increased action of these enzymes at low $\mathrm{pH}$.

Proteolysis of myofibrillar proteins appears to be a major contributor to tenderization during post-mortem storage ${ }^{5,17}$. These proteases may act on sarcoplasmic proteins to produce peptides and amino acids. However, there are not many reports ${ }^{14,15)}$ on the effect of sarcoplasmic proteins compared with myofibrillar proteins. In preliminary experiments, HPLC patterns reveal that the sarcoplasmic protein content decreased, and the peptide and amino acid content increased in the ES muscle $^{12}$. The amount of peptides and free amino acids are important factors in the ageing of meat, and those improve flavor or taste of meat.

Many studies have reported about changes in myofibrillar proteins after $\mathrm{ES}^{1,3,19)}$, but there is little data on peptide and free amino acid content. The objective of this experiment is to examine the accumulation of peptides and free amino acids and the proteolysis of sarcoplasma in stored muscle homogenate and stored sarcoplasma treated with ES.

\section{Materials and Methods}

Preparation of ES muscle homogenate and sarcopiasma: Nine Hereford steers, 25 months old and $650 \mathrm{~kg}$ averge live weight, were fed at Shintoku Animal Husbandry Experiemntal Station and slaughtered at Tokachi Meat Packer Inc. Low voltage $(40 \mathrm{~V}, 13.8 \mathrm{~Hz})$ ES was carried out on each of 3 steers for 30 or $60 \mathrm{sec}$ within $5 \mathrm{~min}$ after slaughter. Three steers were used as controls. Two hours after slaughter, samples of $M$. biceps femoris were obtained and homogenized with $30 \mathrm{mM}$ citratephosphate buffer containing $0.1 \mathrm{M} \mathrm{NaCl}$ and
$0.05 \% \mathrm{NaN}_{3}(\mathrm{pH} 5.5)$, which was three times the volume of the muscle sample. The $\mathrm{pH}$ of these homogenates was approximately 5.6 in each case.

The homogenate was divided into 2 portions, one of which was stored at $2 \pm 1^{\circ} \mathrm{C}$ for $2,7,14$ and 21 days after slaughter. The other portion was prepared for sarcoplasma as follows: It was centrifuged at $11,000 \times \mathrm{g}$ for $20 \mathrm{~min}$ at $1^{\circ} \mathrm{C}$. The supernatant was filtered through Toyo No. $5 \mathrm{c}$ filter paper. This sarcoplasma was also stored under the same conditions as the homogenate. These samples were prepared for peptide and free amino acid content analysis $0,2,7$, 14 and 21 days after slaughter.

Determination of peptides and free amino acids: Samples for analysis of peptides and free amino acids were prepared from the stored homogenate and the stored sarcoplasma. After storage, $15 \mathrm{~g}$ of the homogenate was centrifuged at $11,000 \times \mathrm{g}$ as described above. The supernatant (sarcoplasma) was mixed with an equal volume of $4 \%$ TCA solution, incubated at $37^{\circ} \mathrm{C}$ for $30 \mathrm{~min}$ and centrifuged at $4,500 \times \mathrm{g}$ for $10 \mathrm{~min}$. In the case of the stored sarcoplasma, an equal volume of $4 \%$ TCA was mixed with it in the same way as with the homogenate samples. The filtrate was used for analysis of peptides and free amino acids (Fig. 1). Peptide content was determined using the Lowry method with bovine serum albumin as a standard. Free amino acid analysis was carried out on a fully automated amino acid analyzer (JASCO Model 8000 series) and was determined by the OPA reagent method.

\section{Results and Discussion}

Peptide content: The average peptide contents of the samples are shown in Table 1. The effect of ES treatment on peptide production was observed soon after slaughter. On day 0 ( $6 \mathrm{hrs}$ ) after slaughter, there was a significant difference in peptide content between the control ( $162.5 \mathrm{mg}$ per $100 \mathrm{~g}$ meat), and the ES 30 
and the ES 60 homogenates (192.1 and $198.6 \mathrm{mg}$ per $100 \mathrm{~g}$ meat, respectively). Similar results were reported on peptide contents for the ES homogenate of Holstein cows ${ }^{12)}$; which were also greater than the control 2 days after slaughter. These values increased during storage, and there were significant differences between the control and the ES homogenates on each day. Peptide content at 21 days grew to $356.4,409.7$ and $404.5 \mathrm{mg}$ per $100 \mathrm{~g}$ meat in the control, the ES 30 and the ES 60 homogenates, respectively. The peptide contents in the ES 30 and the ES 60 homogenates were $53.3 \mathrm{mg}$ and $49.1 \mathrm{mg}$ higher than that of the control stored for 21 days after slaughter. The incresaing amount of peptides in the ES homogenates was observed at all stages after slaughter as previously reported ${ }^{12)}$; peptide contents increased appoximately two fold compared to six hours after slaughter. NishimurA et al. ${ }^{13)}$ reported that the peptide contents of beef rounds rose from $208 \mathrm{mg}$ at 4 days to $251 \mathrm{mg}$ per $100 \mathrm{~g}$ meat at 12 days ; an insignificant change. However, the peptide content in the control at 0 and 21 days in this experiment were similar to those of Japanese black cattle ${ }^{16)}$. From above values, one sees that ES treatment is effective in increasing peptide content. One may also conclude from this experiment that the high peptide content is due to the high activity of endogenous proteinases on the weakening of inhibitor for these in the ES homogenates.

DRANSFIELD ${ }^{2)}$ described the proteolysis mechanism that operates during meat tenderization when calpain I becomes active at about $\mathrm{pH} 6.3$ or about 6 hrs after slaughter in beef. At about 16 hrs, calpain II becomes active. As ES hastens reduction in muscle $\mathrm{pH}$, calpain I may play a role in post-mortem proteolysis in the ES meat at an early stage after slaughter, though only for a short period of high $\mathrm{pH}$ and high temperature.

To investigate the origins of these peptides, whether they derived from myofibrillar proteins or sarcoplasmic proteins, peptide contents were determined for the stored sarco-

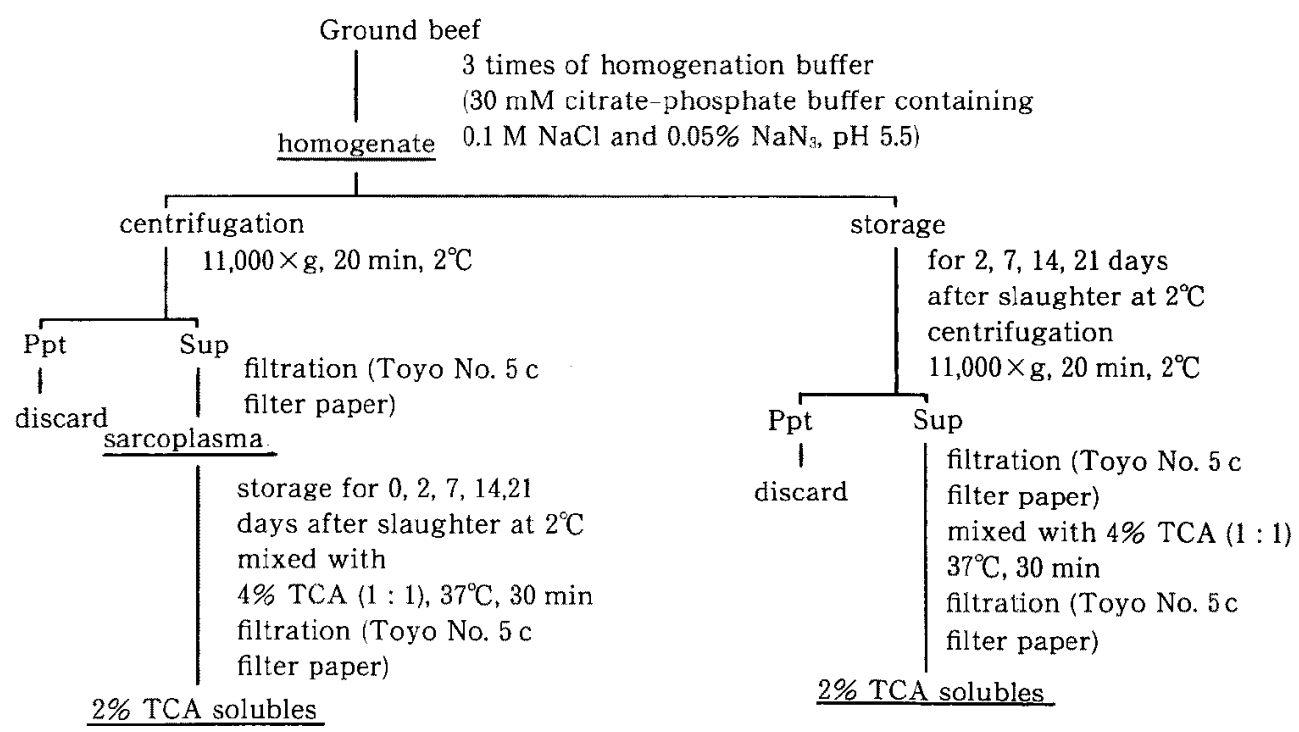

Fig. 1. Experimental scheme and sample preparation.

Beef samples were obtained from $M$. biceps femoris of Hereford steers $2 \mathrm{hrs}$ after slaughter.

Two \% TCA solubles were analyzed for peptide and free amino acid contents. 
plasma also. In the case of the stored sarcoplasma, similar increasing trend were also seen in the control and the ES homogenates during storage. However, the increments in the control and the ES sarcoplasma were less than that of the stored homogenates. Peptide contents in the control, the ES 30 and the ES 60 sarcoplasma were $253.9,291.8$ and $299.0 \mathrm{mg}$ per $100 \mathrm{~g}$ meat at 21 days, respectively ; there were significant differences between the control and the ES sarcoplasma. The increments of peptides were $91.1,99.7$ and $100.4 \mathrm{mg}$ during storage for 21 days in the control, the ES 30 and ES60 sarcoplasma, respectively. These values corresponded to $47.0,45.8$ and $48.5 \%$ of the values in the case of homogenate storage, respective1y. This indicates that ES activates the endogenous proteinase which produces peptides from the proteins, and that these peptides ori- ginate not only in myofibrillar proteins but also in sarcoplasmic proteins and that about half of the peptides produced during storage are derived from sarcoplasma.

GEORGE et $a{ }^{6)}$ reported that the precipitation of sarcoplasmic proteins was observed on the myofibrils of ES muscle via electron microscopy. Precipitation of sarcoplasmic proteins was also reported by SCOPES ${ }^{20)}$ and in our experiment, precipitation was also observed during storage of sarcoplasma. However, peptide contents in the ES sarcoplasma were greater than in the control.

It is well known that there are two proteolytic systems of endogenous proteinases (calpains and cathepsins) in post-mortem muscle ${ }^{7,17,18)}$. Recently, KoohmaraIE ${ }^{8)}$ reported the results of his experiments regarding the mechanism of meat tenderization during post-

Table 1. Changes in peptide content of homogenate and sarcoplasma during storage (mg per $100 \mathrm{~g}$ meat)

\begin{tabular}{|c|c|c|c|c|c|c|}
\hline \multirow{2}{*}{$\begin{array}{c}\text { Days } \\
\text { post-mortem }\end{array}$} & \multicolumn{3}{|c|}{ Homogenate storage } & \multicolumn{3}{|c|}{ Sarcoplasma storage } \\
\hline & Control & ES 30 & ES 60 & Control & ES 30 & $\operatorname{ES} 60$ \\
\hline $0^{\mathrm{a}}$ & $162.5 \pm 6.3$ & $192.1 \pm 0.9^{* *}$ & $198.6 \pm 3.2^{* * *}$ & $162.5 \pm 6.3$ & $192.1 \pm 0.9^{* *}$ & $198.6 \pm 3.2^{* *}$ \\
\hline 2 & $199.1 \pm 2.7$ & $229.1 \pm 2.5^{* *}$ & $236.6 \pm 1.3^{* *}$ & $182.5 \pm 4.6$ & $214.4 \pm 3.2^{* *}$ & $214.6 \pm 3.6^{* *}$ \\
\hline 7 & $270.7 \pm 8.5$ & $310.3 \pm 5.5^{* *}$ & $307.3 \pm 5.5^{* *}$ & $206.6 \pm 6.7$ & $242.9 \pm 4.6^{* *}$ & $244.4 \pm 2.0^{* *}$ \\
\hline 14 & $324.3 \pm 19.4$ & $366.4 \pm 6.8^{*}$ & $367.4 \pm 12.0$ & $226.1 \pm 6.2$ & $272.5 \pm 6.3^{* *}$ & $270.5 \pm 4.7^{* *}$ \\
\hline 21 & $356.4 \pm 26.4$ & $409.7 \pm 4.5^{*}$ & $405.5 \pm 10.3$ & $253.9 \pm 9.1$ & $291.8 \pm 10.9^{*}$ & $299.0 \pm 8.1^{* *}$ \\
\hline
\end{tabular}

: Zero day refers to measurements 6 hrs after slaughter. Data are expressed as an average of 3 cattle and S.E. Asterisks $\left(^{*}: 5 \%,{ }^{* *}: 1 \%\right)$ show the significant level of mean differences between control and ES 30 , and ES 60 .

Table 2. Changes in total free amino acid content of homogenate and sarcoplasma during storage (mg per $100 \mathrm{~g}$ meat)

\begin{tabular}{|c|c|c|c|c|c|c|}
\hline \multirow{2}{*}{$\begin{array}{c}\text { Days } \\
\text { post-mortem }\end{array}$} & \multicolumn{3}{|c|}{ Homogenate storage } & \multicolumn{3}{|c|}{ Sarcoplasma storage } \\
\hline & Control & ES 30 & $\mathrm{ES} 60$ & Control & $\mathrm{ES} 30$ & $\mathrm{ES} 60$ \\
\hline $0^{*}$ & $103.25 \pm 2.34$ & $104.11 \pm 2.85$ & $107.34 \pm 6.93$ & $103.25 \pm 2.34$ & $104.11 \pm 2.85$ & $107.34 \pm 6.93$ \\
\hline 2 & $105.99 \pm 1.73$ & $112.77 \pm 4.36$ & $117.08 \pm 9.73$ & $105.54 \pm 2.21$ & $106.76 \pm 4.25$ & $116.53 \pm 12.43$ \\
\hline 7 & $123.86 \pm 2.67$ & $122.65 \pm 2.00$ & $139.87 \pm 12.37$ & $120.97 \pm 3.56$ & $123.08 \pm 6.92$ & $130.35 \pm 10.72$ \\
\hline 14 & $147.65 \pm 6.46$ & $152.88 \pm 5.28$ & $153.62 \pm 9.53$ & $129.58 \pm 2.28$ & $137.90 \pm 4.82$ & $132.57 \pm 11.50$ \\
\hline 21 & $175.55 \pm 5.75$ & $175.58 \pm 5.01$ & $130.28 \pm 6.76$ & $153.61 \pm 1.60$ & $149.88 \pm 3.52$ & $146.65 \pm 9.09$ \\
\hline
\end{tabular}

*Zero day refers to measurements 6 hrs after slaughter. Data are expressed as an average of 3 cattle and S.E. 
mortem storage and decribed that three endopeptidases were involved in post-mortem proteolysis: 1) the lysosomal cathepsins ; 2) the multicatalytic protease complex (MCP) ; 3) the calpains. However, he concluded that cathepsins and MCP do not play a major role in post-mortem proteolysis and that calpain proteolytic system is responsible for post-mortem proteolysis that results in "meat tenderization". As the authors ${ }^{12)}$ reported previously, peptide contents in the ES muscle homogenate increased more than in the control homogenate even after addition of $1 \mathrm{mM}$ EDT $\mathrm{A}$ which is an inhibitor of calpains and is an activator of cathepsin $\mathrm{B}$ and $\mathrm{L}$. The $\mathrm{pH}$ of meat treated with ES was below 6.0, 2 hrs after slaughter, and homogenates used in both experiments had a $\mathrm{pH}$ of 5.6. These results show that proteolysis in post-mortem muscles are taken place by not only calpains but also cathepsins.
Free amino acid content: Table 2 shows the total amount of 18 free amino acids in the homogenate and the sarcoplasma stored at $2^{\circ} \mathrm{C}$ until 21 days after slaughter. The total amount of free amino acids increased each day during storage; values were 103.3, 104.1 and $107.3 \mathrm{mg}$ in the control, the ES 30 and the ES 60 homogeneates six hours after slaughter, and $175.6,175.6$ and $180.3 \mathrm{mg}$ per $100 \mathrm{~g}$ meat 21 days after slaughter, respectively. There was no significant difference between the control and the ES homogenates. In our previous report ${ }^{12)}$, amino acid contents were greater than those of the present experiment. This reason is due to the method of analysis; i.e. at that time, amino acid content was measured with ninhydrin positive materials but this time, 18 free amino acids were summed using an amino acid analyzer.

The total amount of free amino acids also

Table 3. Free amino acid composition of the control and the ES homogenates (mg per $100 \mathrm{~g}$ meat)

\begin{tabular}{|c|c|c|c|c|c|c|}
\hline \multirow{2}{*}{ Amino acid } & \multicolumn{3}{|c|}{0 day after slaughter } & \multicolumn{3}{|c|}{2 days after slaughter } \\
\hline & Control & ES 30 & ES 60 & Control & ES 30 & $\operatorname{ES} 60$ \\
\hline Asp & $0.51 \pm 0.03$ & $0.80 \pm 0.12$ & $0.68 \pm 0.01$ & $0.85 \pm 0.12$ & $1.05 \pm 0.17$ & $1.04 \pm 0.06$ \\
\hline Thr & $2.94 \pm 0.13$ & $2.84 \pm 0.08$ & $2.82 \pm 0.08$ & $3.01 \pm 0.09$ & $2.95 \pm 0.16$ & 3. $13 \pm 0.10$ \\
\hline Ser & 4. $26 \pm 0.12$ & $4.21 \pm 0.35$ & $4.08 \pm 0.27$ & 4. $43 \pm 0.15$ & $4.60 \pm 0.30$ & $4.55 \pm 0.35$ \\
\hline Asn & $4.94 \pm 0.36$ & $4.92 \pm 0.33$ & $4.31 \pm 0.19$ & $5.06 \pm 0.29$ & $5.63 \pm 0.57$ & $5.34 \pm 0.22$ \\
\hline Glu & $18.44 \pm 1.53$ & $21.43 \pm 2.01$ & $25.18 \pm 3.11$ & $16.71 \pm 1.07$ & $24.89 \pm 3.18$ & $25.26 \pm 3.58$ \\
\hline Pro & $2.43 \pm 0.19$ & $2.60 \pm 0.07$ & $2.22 \pm 0.14$ & $2.28 \pm 0.19$ & $2.59 \pm 0.04$ & $2.27 \pm 0.18$ \\
\hline Gly & $8.08 \pm 0.10$ & 7. $13 \pm 0.72$ & $7.23 \pm 0.64$ & $7.77 \pm 0.10$ & 7. $05 \pm 0.49$ & $7.57 \pm 0.82$ \\
\hline $\mathrm{Ala}$ & $35.21 \pm 0.83$ & 33. $16 \pm 1.14$ & $34.41 \pm 2.96$ & $33.83 \pm 0.61$ & $31.03 \pm 0.68$ & 34. $48 \pm 4.24$ \\
\hline $\mathrm{Val}$ & $3.55 \pm 0.24$ & $3.53 \pm 0.31$ & $3.17 \pm 0.17$ & $3.70 \pm 0.19$ & $3.86 \pm 0.45$ & $3.89 \pm 0.08$ \\
\hline Cys & $1.38 \pm 0.29$ & 1. $14 \pm 0.19$ & $0.89 \pm 0.17$ & 1. $30 \pm 0.27$ & $0.76 \pm 0.08$ & 1. $53 \pm 0.29$ \\
\hline Met & $0.43 \pm 0.09$ & $0.48 \pm 0.02$ & $0.45 \pm 0.03$ & $1.04 \pm 0.14$ & $1.14 \pm 0.11$ & $1.27 \pm 0.07$ \\
\hline Ile & $1.77 \pm 0.28$ & $1.88 \pm 0.12$ & $1.80 \pm 0.01$ & $2.48 \pm 0.09$ & $2.53 \pm 0.17$ & $2.69 \pm 0.14$ \\
\hline Leu & 3. $24 \pm 0.16$ & 3. $14 \pm 0.25$ & $3.01 \pm 0.09$ & 4. $11 \pm 1.14$ & $4.27 \pm 0.38$ & $4.42 \pm 0.07$ \\
\hline Tyr & $1.95 \pm 0.14$ & $1.91 \pm 0.14$ & $2.03 \pm 0.09$ & $2.45 \pm 0.13$ & $2.43 \pm 0.18$ & $2.70 \pm 0.07$ \\
\hline Phe & $1.51 \pm 0.06$ & $1.59 \pm 0.06$ & $1.71 \pm 0.04$ & $2.68 \pm 0.03$ & $3.07 \pm 0.16$ & $3.14 \pm 0.04$ \\
\hline Lys & $3.84 \pm 0.15$ & $4.13 \pm 0.42$ & $3.88 \pm 0.33$ & $4.37 \pm 0.31$ & $4.61 \pm 0.53$ & $4.36 \pm 0.63$ \\
\hline His & $4.67 \pm 0.26$ & $4.67 \pm 0.22$ & $5.34 \pm 0.10$ & 4. $76 \pm 0.32$ & $5.54 \pm 0.39$ & $5.03 \pm 0.34$ \\
\hline Arg & $3.95 \pm 0.39$ & $4.55 \pm 0.49$ & 4. $13 \pm 0.06$ & $5.16 \pm 0.34$ & $4.76 \pm 0.42$ & $4.42 \pm 0.12$ \\
\hline Total & 103. $25 \pm 2.34$ & $104.11 \pm 2.85$ & $107.34 \pm 6.93$ & $105.99 \pm 1.73$ & $112.77 \pm 4.36$ & $117.08 \pm 9.73$ \\
\hline
\end{tabular}

Zero day refers to measurements 6 hrs after slaughter. Data are expressed as an average of 3 cattle and S.E. 
increased in the stored sarcoplasma, although it was less than that of the stored homogenate. The total amount in the control and the ES sarcoplasma ranged between $146.7-153.6 \mathrm{mg}$ per $100 \mathrm{~g}$ meat 21 days after slaughter. Increments of free amino acids measured 50.4, 45.8 and $39.3 \mathrm{mg}$ during storage for 21 days in the control, the ES 30 and the ES60 sarcoplasma, respectively. These values corresponded to $69.7,64.0$ and $53.9 \%$ of the values in the case of homogenate storage, respectively. These results indicate that increased free amino acids originate mainly from peptides or sarcoplasmic proteins in the sarcoplasma rather than in the myofibrillar proteins. Although ES treatment produced much peptides from the both homogenate and sarcoplasma (Table 1), it had no effect on the total amount of free amino acids in the ES homogenates or the ES sarcoplasma.

OKAYAMA et $a l .{ }^{14)}$ reported the increase of free amino acids in $M$. Semimembranosus during the conditioning of Japanese black cattle. The total amount of 18 free amino acids measured $68.5,218.7,258.0$ and $269.8 \mathrm{mg}$ per $100 \mathrm{~g}$ meat 0,7 , 14 and 21 days after slaughter, respectively. The amount on day 0 was lower than that of this experiment, but amounts at 7, 14 and 21 days were much higher than those of this experiment.

Free amino acid composition in the both homogenate and sarcoplasma is shown in Table 3, 4 and 5. Almost all free amino acids increased during storage of the control and the ES homogenates except Cys, Pro and Gly. Cys did not increase during storage and increment of Pro was little. Although Gly had the third highest content of the 18 free amino acids on day 0 , growth was small and Gly became the forth-ranked amino acid in the control and the ES homogenates 21 days after slaughter. On the other hand, Leu increased greatly during storage and became the third highest content

Table 4. Free amino acid composition of the control and the ES homogenates (mg per $100 \mathrm{~g}$ meat)

\begin{tabular}{|c|c|c|c|c|c|c|}
\hline \multirow{2}{*}{ Amino acid } & \multicolumn{3}{|c|}{7 days after slaughter } & \multicolumn{3}{|c|}{21 days after slaughter } \\
\hline & Control & ES 30 & ES 60 & Control & ES 30 & ES 60 \\
\hline Asp & $1.41 \pm 0.19$ & $1.60 \pm 0.26$ & $1.83 \pm 0.24$ & $2.44 \pm 0.29$ & $2.24 \pm 0.16$ & $2.55 \pm 0.21$ \\
\hline Thr & $3.65 \pm 0.13$ & $3.28 \pm 0.06$ & $3.57 \pm 0.31$ & $5.52 \pm 0.20$ & $4.77 \pm 0.08$ & $4.81 \pm 0.18$ \\
\hline Ser & $5.66 \pm 0.07$ & $5.12 \pm 0.40$ & $5.70 \pm 0.55$ & $8.47 \pm 0.24$ & $7.57 \pm 0.49$ & $7.42 \pm 0.34$ \\
\hline Asn & $5.82 \pm 0.38$ & $6.60 \pm 0.58$ & $6.61 \pm 0.56$ & $8.42 \pm 0.07$ & $8.89 \pm 0.76$ & $8.95 \pm 0.20$ \\
\hline Glu & $17.83 \pm 0.82$ & $25.07 \pm 3.12$ & $29.57 \pm 4.59$ & 23. $34 \pm 1.42$ & $31.07 \pm 3.86$ & $32.04 \pm 4.08$ \\
\hline Pro & $2.76 \pm 0.09$ & $2.67 \pm 0.11$ & $2.28 \pm 0.26$ & $4.20 \pm 0.09$ & $3.72 \pm 0.23$ & $3.33 \pm 0.51$ \\
\hline Gly & $8.12 \pm 0.39$ & $7.02 \pm 0.78$ & $8.22 \pm 0.89$ & $9.87 \pm 0.50$ & $8.66 \pm 0.85$ & $9.18 \pm 0.88$ \\
\hline $\mathrm{Ala}$ & $34.66 \pm 1.20$ & $29.63 \pm 1.57$ & $35.90 \pm 3.86$ & $40.52 \pm 0.40$ & $35.48 \pm 1.13$ & $38.87 \pm 3.84$ \\
\hline Val & $4.79 \pm 0.36$ & $4.57 \pm 0.32$ & $5.01 \pm 0.20$ & $7.57 \pm 0.45$ & $7.33 \pm 0.26$ & $7.04 \pm 0.12$ \\
\hline Cys & $1.57 \pm 0.22$ & $1.07 \pm 0.18$ & $1.32 \pm 0.17$ & $1.39 \pm 0.26$ & $1.49 \pm 0.05$ & $1.48 \pm 0.32$ \\
\hline Met & $2.83 \pm 0.25$ & $2.38 \pm 0.26$ & $2.66 \pm 0.19$ & $5.45 \pm 0.78$ & $5.25 \pm 0.16$ & $5.17 \pm 0.43$ \\
\hline Ile & $3.78 \pm 0.03$ & $3.75 \pm 0.10$ & $4.21 \pm 0.24$ & $6.33 \pm 0.45$ & $7.02 \pm 0.15$ & $7.57 \pm 1.12$ \\
\hline Leu & $6.30 \pm 0.18$ & $6.39 \pm 0.19$ & $7.01 \pm 0.32$ & $11.53=1.08$ & $12.62 \pm 0.11$ & $12.71 \pm 1.09$ \\
\hline Tyr & $4.09 \pm 0.13$ & $3.62 \pm 0.24$ & $3.96 \pm 0.20$ & $7.83 \pm 0.54$ & $7.24 \pm 0.24$ & $6.94 \pm 0.41$ \\
\hline Phe & $4.52 \pm 0.15$ & $4.69 \pm 0.07$ & $5.17 \pm 0.26$ & $8.49 \pm 0.75$ & $9.00 \pm 0.03$ & $8.89 \pm 0.47$ \\
\hline Lys & $5.16 \pm 0.34$ & $5.32 \pm 0.64$ & $5.38 \pm 0.51$ & $8.62 \pm 0.19$ & $8.77 \pm 0.41$ & $8.97 \pm 0.35$ \\
\hline His & $5.36 \pm 0.41$ & $5.39 \pm 0.21$ & $6.03 \pm 0.30$ & $6.90 \pm 0.20$ & $6.80 \pm 0.08$ & $6.82 \pm 0.12$ \\
\hline Arg & $5.56 \pm 0.46$ & $5.02 \pm 0.39$ & $5.45 \pm 0.25$ & $8.66 \pm 0.64$ & $7.66 \pm 0.76$ & $7.54 \pm 0.23$ \\
\hline Total & $123.86 \pm 2.67$ & $122.65 \pm 2.00$ & $139.87 \pm 12.37$ & $175.55 \pm 5.75$ & $175.58 \pm 5.01$ & $180.28 \pm 6.76$ \\
\hline
\end{tabular}

Data are expressed as an average of 3 cattle and S.E. 
Mikami, Nagao, Sekikawa, Miura and Hongo

Table 5. Free amino acid composition of the control and the ES sarcoplama (mg per $100 \mathrm{~g}$ meat)

\begin{tabular}{|c|c|c|c|c|c|c|}
\hline \multirow{2}{*}{ Amino acid } & \multicolumn{3}{|c|}{7 days after slaughter } & \multicolumn{3}{|c|}{21 days after slaughter } \\
\hline & Control & ES 30 & $\operatorname{ES} 60$ & Control & ES 30 & ES 60 \\
\hline Asp & $0.44 \pm 0.18$ & $0.92 \pm 0.10$ & $1.08 \pm 0.01$ & $0.91 \pm 0.06$ & $1.26 \pm 0.06$ & $1.41 \pm 0.18$ \\
\hline Thr & $3.23 \pm 0.12$ & $2.95 \pm 0.06$ & $3.29 \pm 0.18$ & $3.67 \pm 0.15$ & $3.54 \pm 0.15$ & $3.85 \pm 0.19$ \\
\hline Ser & $4.73 \pm 0.10$ & $4.95 \pm 0.44$ & $5.15 \pm 0.41$ & $5.88 \pm 0.07$ & $6.00 \pm 0.31$ & $6.07 \pm 0.41$ \\
\hline Asn & $5.53 \pm 0.40$ & $5.41 \pm 0.30$ & $5.64 \pm 0.38$ & $5.63 \pm 0.16$ & $6.57 \pm 0.54$ & $7.12 \pm 0.67$ \\
\hline Glu & $30.82 \pm 2.47$ & $29.37 \pm 4.09$ & $29.42 \pm 4.56$ & $47.36 \pm 2.20$ & $33.55 \pm 5.50$ & $30.80 \pm 4.38$ \\
\hline Pro & $2.69 \pm 0.15$ & $2.38 \pm 0.09$ & $2.37 \pm 0.23$ & $3.08 \pm 0.29$ & $2.92 \pm 0.07$ & $2.88 \pm 0.11$ \\
\hline Gly & $8.60 \pm 0.14$ & $7.78 \pm 0.84$ & $8.31 \pm 0.75$ & $9.71 \pm 0.12$ & $8.50 \pm 0.75$ & $8.88 \pm 0.85$ \\
\hline Ala & $30.64 \pm 0.61$ & $33.81 \pm 2.65$ & $37.95 \pm 3.97$ & $31.25 \pm 1.84$ & $37.39 \pm 1.97$ & $35.73 \pm 1.66$ \\
\hline Val & $4.09 \pm 0.26$ & $4.58 \pm 0.20$ & $4.91 \pm 0.12$ & $5.62 \pm 0.31$ & $6.42 \pm 0.38$ & $6.46 \pm 0.56$ \\
\hline Cys & $1.90 \pm 0.26$ & $0.87 \pm 0.32$ & $1.33 \pm 0.44$ & $0.70 \pm 0.25$ & $0.65 \pm 0.11$ & $1.53 \pm 0.29$ \\
\hline Met & $1.05 \pm 0.04$ & $1.36 \pm 0.18$ & $1.63 \pm 0.07$ & $1.92 \pm 0.15$ & $2.73 \pm 0.28$ & $2.61 \pm 0.27$ \\
\hline Lle & $2.69 \pm 0.12$ & $2.72 \pm 0.11$ & $2.95 \pm 0.01$ & $3.73 \pm 0.21$ & $4.11 \pm 0.16$ & $4.30 \pm 0.61$ \\
\hline Leu & $4.69 \pm 0.18$ & $4.64 \pm 0.22$ & $4.78 \pm 0.16$ & $7.25 \pm 0.49$ & $7.18 \pm 0.42$ & $6.97 \pm 0.74$ \\
\hline Tyr & $3.35 \pm 0.29$ & $3.22 \pm 0.19$ & $3.48 \pm 0.08$ & $5.10 \pm 0.41$ & $4.95 \pm 0.23$ & $5.13 \pm 0.57$ \\
\hline Phe & $2.47 \pm 0.14$ & $2.38 \pm 0.04$ & $2.67 \pm 0.12$ & $4.01 \pm 0.25$ & $4.13 \pm 0.07$ & 4. $28 \pm 0.53$ \\
\hline Lys & $4.83 \pm 0.27$ & 5. $11 \pm 0.62$ & $5.19 \pm 0.29$ & $6.04 \pm 0.10$ & $\% .19 \pm 0.75$ & $6.98 \pm 0.80$ \\
\hline His & $4.83 \pm 0.29$ & $5.65 \pm 0.29$ & $5.73 \pm 0.10$ & $6.30 \pm 0.32$ & $6.68 \pm 0.41$ & $6.12 \pm 0.10$ \\
\hline Arg & $4.40 \pm 0.55$ & $4.99 \div 0.62$ & $4.48 \pm 0.45$ & $5.47 \pm 0.37$ & $6.09 \pm 0.24$ & $5.52 \pm 0.62$ \\
\hline Total & $120.97 \pm 3.56$ & $123.08 \pm 6.92$ & $130.35 \pm 10.72$ & $153.61 \pm 1.60$ & $149.88 \pm 3.52$ & $146.65 \pm 9.09$ \\
\hline
\end{tabular}

Data are expressed as an average of 3 cattle and S.E.

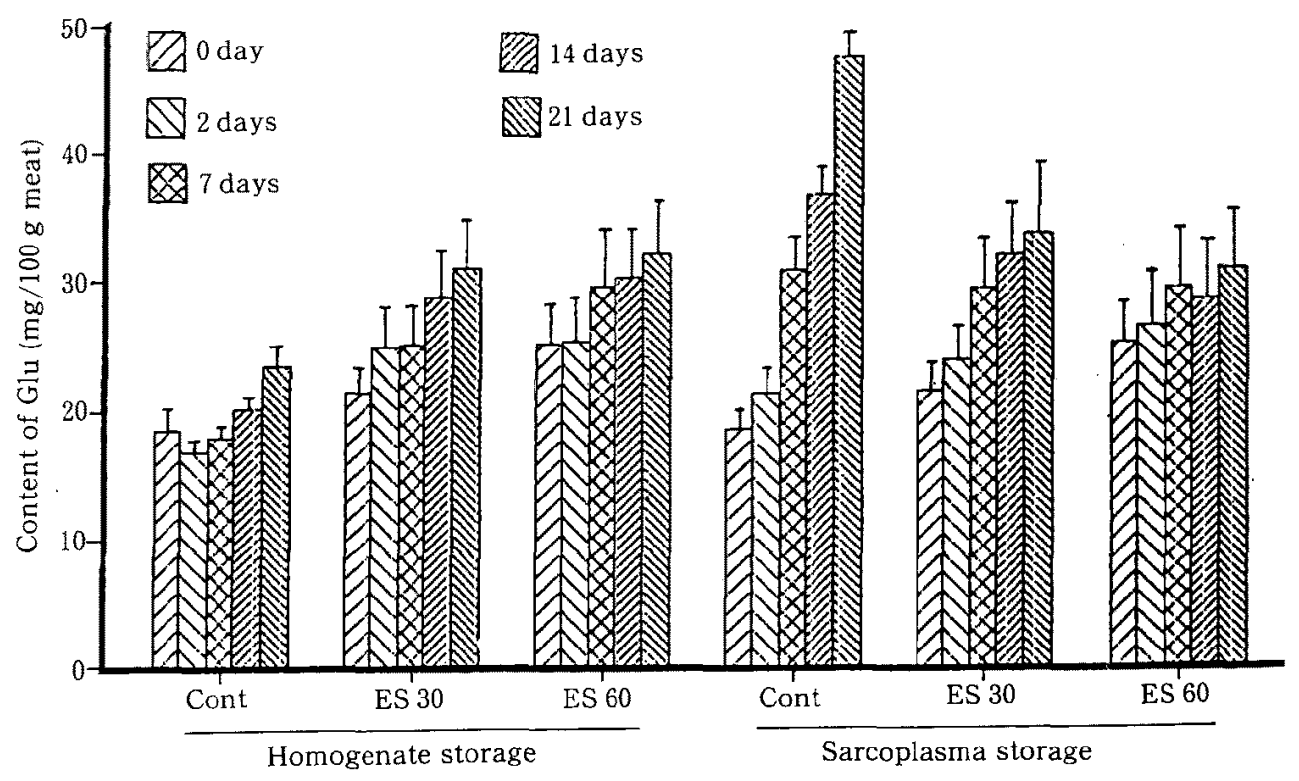

Fig. 2. Changes in Glu content during the storage of homogenate and sarcoplasma. Bars mean S.E. 
in the control and the ES homogenates 21 days after slaughter.

A remarkable change was observed in the case of Glu, among the control and the ES homogenantes (Table 3 and 4, Fig. 2). The content of Glu increased after ES treatment from day 0 , measuring $18.4,21.4$ and $25.2 \mathrm{mg}$ per $100 \mathrm{~g}$ meat in the control, the ES 30 and the ES 60 homogenates, respectively. This increasing trend was seen until 21 days after slaughter; the content of Glu increased to $23.3,31.1$ and $32.0 \mathrm{mg}$ at 21 days, respectively. Glu content was 2.81 and $21.34 \mathrm{mg}$ in the M. Semimembranosus of Japanese black cattle 0 and 7 days after slaughter ${ }^{14)}$, and 6.03 and $9.71 \mathrm{mg}$ in beef round 4 and 12 days after slaughter ${ }^{13)}$. In the present study, the content of Glu in the ES homogenates were higher than that of the control in this experiment or the these both reports.

Another amino acid which increased due to ES treatment was Phe in the both ES homogenates at 0,2 and 7 days, although there was little growth. On the contrary, there was a decrease in free amino acids with ES treatment in the case of Pro, Try and Arg in the ES homogenates at 2, 7 and 21 days.

On the other hand, in the stored sarcoplasma, content of almost all free amino acids increased during storage, but was lower than those of the homogenates in storage except Glu, Gly and Ala (Table 5). The content of Glu in the control sarcoplasma increased rapidly during storage and became the highest $(47.36 \mathrm{mg}$ per $100 \mathrm{~g}$ meat) at 21 days, to a level of twice that of the control at day 0 (Table 3, 5 and Fig. 2). According as increment of Glu in the control sarcoplasma, the content of Ala decreased compared to the control homogenate (Table 3, 4 and 5). It is well known that when Ala is changed to pyruvic acid in the metabolism of cell, Glu is produced by alanine aminotransferase. However, the contents of Glu and Ala in the ES sarcoplasma were not different from those of the ES homogenates. The only difference between the control homogenate and the control sarcoplasma was the removal of myofibrils. There was no stimulation to proteases by ES treatment. These results suggest following possibility: myofibrils contain inhibitors of such as Glu aminopeptidases or alanine aminotransferase and by removing the myofibrils, these enzymes may work and produce more Glu. However, it is not clear how Glu is produced in the relation of the control sarcoplasma and the ES homogenates, but one can definitely state that ES treatment changes the balance among enzymes, inhibitors and substrates, thereby producing much Glu.

Previously, the author ${ }^{11)}$ reported a high IMP content in ES muscle in Holstein steers, and now the present study shows that ES treatment caused the accumulation of a large content of peptides and Glu. These results indicate that ES treatment improves the favor of beef.

\section{Acknowledgments}

This study was supported in part by a Grant-in-Aid (No. 05660304) from the Scientific Research Fund of the Ministry of Education, Science and Culture, Japan. The authors also greatly thank Mr. K. Kon, Tokachi Meat Packer Inc., for the ES treatments.

\section{References}

1) BABiKer, S.A., Effect of electrical stimulation, high temperature conditions and ageing on muscle myofibrillar proteins. Meat Sci., $14: 83^{-}$ 90. 1985.

2) DRANSFIELD, E., Optimisation of tenderisation, ageing and tenderness. Meat Sci., $36: 105-121$. 1994.

3) Ducastaing, A., C, Valin, J. Schollmeyer and R. CROSS, Effects of electrical stimulation on post-mortem changes in the activities of two $\mathrm{Ca}$ dependent neutral proteinases and their inhibitor in beef muscle. Meat Sci., 15 : 193-202. 1985.

4) Dutson, T.R., G.C. Smith and Z.L. CARpenter, Lysosomal enzyme distribution in electrically stimulated ovine muscle. J. Food Sci., 45: 1097-1098. 1980. 
5) Erherington, D.J., The contribution of proteolytic enzymes to postmortem changes in muscle. J. Anim. Sci., 59 : 1644-1650. 1984.

6) GEORGE, A.R., J.R. BENDALL and C.D. Jones, The tenderising effect of electrical stimulation of beef carcasses. Meat Sci., 4:51-68. 1980.

7) Goll, D.E., Y. Otsuka, P.A. Nagainis, J.D. Shannon, S.K. Sathe and M. Muguruma, Role of muscle proteinases in maintenance of muscle integrity and mass. J. Food Biochem., 7 : 137-177. 1983.

8) Koohmaraie, M., Muscle proteinases and meat aging. Meat Sci., $36: 93-104.1994$.

9) MARSh, B.B., J.V. LOCHNER, G. TAKAHASHI and D. D. KRAGNESS, Effects of early post-mortem $\mathrm{pH}$ and temperature on beef tenderness. Meat Sci., $5:$ : 479-483. 1980-81.

10) Mikami, M.,T. Kudoh, A. Hayashi, E. Hiruta and H. MrURA, Effects of electrical stimulation on myofibrillar proteins and tenderness of beef muscle. Agric. Biol. Chern., 54 : 531-532. 1990.

11) Mikami, M., Y. Kinoshita and H. MiURA, Changes in ATP related compounds of electrically stimulated beef. Anim. Sci. Technol. (Jpn.), $62: 398-400.1991$.

12) Mikami, M.,Y. Yamada, Y. Wakahara and $H$. MIURA, Effects of electrical stimulation on the sarcoplasmic proteins, peptide and amino acid contents of beef. Anim. Sci. Technol. (Jpn.), 62 : 519-528. 1991.

13) Nishimura, T., M.R. Rhue, A. Okitani and H. KATO, Components contributing to the improvement of meat taste during storage. Agric. Biol. Chem., 52 : 2323-2330. 1988.

14) Okayama, T., H. Kamakari, S. Nakagawa, M. Yamanoue, I. NishikaWA, N. Mirsuishi and K.
KoNISHI, Changes in the physical and chemical properties of muscles during conditioning of Japanese black cattle. Anim. Sci. Technol, (Jpn.) $62:$ 178-185. 1991.

15) Okayama, T., H. Fukumoto, S. Nakagawa, M. Yamanoue and I. Nishikawa, Changes in protein content in subcellular sarcoplasmic fractions of muscles during conditioning of Japanese black cattle. Anim. Sci. Technol. (Jpn.), 63: 855-860. 1992.

16) OKayama, T., K. Shiose, S. Nakagawa, M. Yamanoue and I. Nishikawa, Changes in lowmolecular weight components in sarcoplasmic fraction during conditioning of Japanese black cattle. Anim. Sci. Technol. (Jpn.), 64 : 748-753. 1993.

17) Pearson, A.M., A.M. Wolzak and J.I. Gray, Possible role of muscle proteins in flavor and tenderness of meat. J. Food Biochem., $7: 189-$ 210. 1983.

18) Penny, I.F. and R. Ferguson-Pryce, Measurement of autolysis in beef muscle homogenates. Meat Sci., $3: 121-134.1979$.

19) Pommier, S.A., L.M. Poste and G. ButLer, Effect of low voltage electrical stimulation on the distribution of cathepsin D and the palatability of the Longissimus dorsi from Holstein veal calves fed a corn or barley diet. Meat Sci., 21 : 203-218. 1987.

20) SCOPES, R.K., The influence of post-mortem conditions on the solubilities of muscle proteins. Biochem. J., 9 : 201-207. 1964.

21) Sorinmade, S.O., H.R. Cross, K. Ono and W.P. WERGIN, Mechanisms of ultrastructural changes in electrically stimulated beef Longissimus muscle. Meat Sci., 6 : 71-77. 1982. 


\title{
牛肉ホモジネートおよび筋漿の貯蔵中におけるペプチド および遊離アミノ酸量に及ぼす電気刺激の影響
}

\author{
三上正幸・長尾真理・関川三男・三浦弘之・本郷泰久* \\ 帯広畜産大学, 帯広市 080 \\ * 北海道立新得畜産試験場，北海道新得町 081
}

\begin{abstract}
電気刺激を行なった牛肉の熱成中におけるぺプチドおよび遊離アミノ酸量を知るため,へレフォード 種去勢肥育牛 9 頭に対し，40 V，13.8 Hzで 0 (対照区)，30（ES30区）扰よび60(ES60区) 秒の電気 刺激を行なった。供試筋肉部位は大腿二頭筋を用い，牛肉ホモジネートおよび筋奬画分を調製し， $2^{\circ} \mathrm{Cで}$ 屠殺 0 (6 時間)，2，7，14 および 21 日目まで保存した，ES 30 拈よび ES 60 区のホモジネート保存のぺ プチド量は, 屠殺0日目から対照区のあの上りあ多く，対照区，ES30 およびES60区における量は，そ れぞれ牛肉 $100 \mathrm{~g}$ 当り，162.5，192.1 および $198.6 \mathrm{mg}$ であった，この增加㥧向は 21 日目まで続き，それ ぞれ 356.4, 409.7 および $405.5 \mathrm{mg}$ となった. 総遊離アミ/酸量は保存日数とともに增加したが, 対照区 上電気刺激区の間に差は見られなかった。しかしながら，電気刺激区に招けるグル夕ミン酸量は屠殺 0 日目から增加しており，21 日目には対照区の $23.3 \mathrm{mg}$ (100 g 牛肉中）に対して，ES 30 おょびES 60 区 は 31.1-32.0 mg まで増加した。. ペプチド量およびグルタミン酸量を增加させることから， ES は物肉の 呈味性向上に有勃であることが認められた。一方筋策の状態で保存した場合, ペプチドおよび遊雕アミ ノ酸量は增加したが，その増加量は21 日目において，ホモジネート保存時のそれぞれ 45.8-48.5\%およ び 53.9-69.7\%に相当した.これらのことから,ペプチドおよび遊離アミノ酸の生成は, 筋墏のタンパク 質やペプチドと同様に筋原線維タンパク質にも由来していることが分った.
\end{abstract}

日畜会報, 65 (11)：1034-1043，1994 